\title{
The Influence of Foreign Strategic Investors on the Risk Management of Chinese Commercial Banks
}

\author{
Yang Shuyue, Zhou Guoqiang \\ Management College, Wuhan University of Technology, Wuhan, China \\ 2473639912@qq.com
}

\begin{abstract}
To study the effect of the Chinese commercial banks' introduction of overseas strategic investors and put advice on introducing foreign investment was the topic of the text. The improvement of internationalization has promoted the rapid development of the banking industry, and the banking industry is faced with the increasingly fierce market competition from home and abroad. Many commercial banks have begun to introduce overseas strategic investors, but the outcome of the introduction was unknown because many strategic investors began selling shares to obtain huge returns after the restricted sales period. So it is important to be aware of the effect of the introduction. In this text, the China Construction Bank's (CCB) introduction of the Bank of America (BOA) was put as an example, and after analyzing the influence of the BOA's equity holdings behavior to the CCB in risk management, some suggestions were put forward to improve the effect the introduction of strategic investors.
\end{abstract}

Keywords: China Construction Bank; Overseas strategic investors; Bank of America; Risk management

\section{Introduction}

Since the 90s of last century, the government of China started a gradual reform to solve the problems in the banking system, in which the introduction of strategic investors was a key method. The bank needed the introduction of funds, and also the advanced management experience and technical means. Many Chinese commercialbanks introduced foreign strategic investors in private placement (strategic placement) before or after the IPO. They wanted to improve the corporate governance structure and learn about experience for participating in international competitiveness. But in fact, many strategic investors began to sell the shares of Chinese banks to get huge returns after the expiry of restricted shares, and finally they withdrew from Chinese banks. What was their purpose, cooperation or only for high returns? What kind of influence they have brought? The impact of the introduction of foreign strategic investors on the host country can't simply be defined as positive or negative.

\section{Literature Review}

There are a large number of scholars to study the impact of China commercial banks' introduction of foreign strategic investors, but there is no consistent conclusion. Sun and Lan (2008) found that foreign ownership and the proportion of bank performance were not necessarily linked. Zhang and Song (2010) analyzed the effect of the introduction of overseas strategic investors by listed banks, and found that the introduction of overseas strategic investors could effectively improve the corporate governance mechanism. Zhu and $\mathrm{Li}$ (2010) analyzed the short-term effects of the introduction of strategic investors, and found that the introduction of strategic investors could improve the capital adequacy level, innovation capacity and operational efficiency, but could not improve the bank's asset quality and profitability. Wei (2016) thought that Chinese banks could cooperate with foreign strategic investors to optimize and upgrade intangible resources. Xing and Pang (2016) found that the strategic investors were financial speculators, and state-owned commercial banks couldn't obtain advanced technology or management experience.

To study the effectiveness of the CCB's introduction of the BOA, the BOA's equity holding behavior is analyzed in Section 3 firstly, then after discussing the changes of different risk indexes in Section 4, the suggestions are made in Section 5 to provide advice for the future introduction of foreign investment. 


\section{The CCB's Cooperation with the BOA}

On March 26, 1996, the People's Construction Bank of China established in 1954 officially changed its name to the China Construction Bank, and the Bank of America is among the best commercial banks in the United States. On June 17, 2005, the BOA spent \$ 2.5 billion to hold 8.19\% stake in the CCB. Under the agreement, the BOA could increase its stake to $19.9 \%$ in the next few years. At the same time, the BOA would provide strategic assistance to the $\mathrm{CCB}$ in many fields which included corporate governance, risk management, information technology, financial management and so on. On August 24, 2006, the CCB and the BOA signed an acquisition agreement to acquire the entire issued shares of the BOA (Asia) for HK $\$ 9.71$ billion. On December 28, 2007, the CCB and the BOA jointly established the CCB Financial Leasing Corporation Limited, and the strategic cooperation had entered a more in-depth stage. On May 28, 2008, the BOA exercised its call option to buy 6 billion $\mathrm{H}$ shares of the CCB. After the trade, the BOA increased its stake to $10.75 \%$. In November 2008, the BOA bought 195.8 billion $\mathrm{H}$ shares from Central Huijin Investment Ltd., and the proportion reached $19.13 \%$, which was close to the shareholding ceiling.

But the BOA began to reduce its stake of the CCB at the end of partial lock-up period. In January 2009, the BOA sold the CCB's shares for the first time, causing the price of $\mathrm{H}$ shares fell $8.76 \%$ in the day. Its largest reduction occurred in May 2009, from which 7.3 billion US dollars cash was earned. On November, 2010, the BOA directly transferred equity placement rights because of short cash. On August 30, 2010, the BOA sold 13.1 billion shares of $\mathrm{H}$ shares, and got after-tax profit of 3.3 billion US dollars. Several reductions led to the fact that the shares held by BOA dropped to about 5\%. In the first half of 2013, the BOA also held 2 billion shares of the CCB, but by September 2013, the BOA fully cleared its holdings.

\section{The Comparative Analysis on the Financial Risk Indexes of the CCB}

In order to know the financial risk situation of the $\mathrm{CCB}$ before and after the introduction of BOA, the financial risks of CCB through their vertical comparison are discussed from 2004 to 2015, which includes capital risk, asset quality risk, liquidity risk, profitability risk.

Table 1

Financial risk assessment index of commercial banks

\begin{tabular}{|c|c|c|}
\hline Overall risk & Risk classification & Risk evaluation index \\
\hline \multirow{11}{*}{$\begin{array}{l}\text { Financial risk } \\
\text { evaluation index }\end{array}$} & \multirow{3}{*}{ Capital risk } & Capital adequacy ratio \\
\hline & & Core capital adequacy ratio \\
\hline & & Total asset-liability ratio \\
\hline & \multirow{3}{*}{ Asset quality risk } & Non-performing loan ratio \\
\hline & & Provision coverage ratio \\
\hline & & Maximum ten customer loan ratios \\
\hline & \multirow{2}{*}{ Liquidity risk } & Current ratio \\
\hline & & Deposit and loan ratio \\
\hline & \multirow{3}{*}{ Profitability risk } & Asset profit ratio \\
\hline & & Rate of return on capital \\
\hline & & Earnings per share (EPS) \\
\hline
\end{tabular}

\subsection{Capital Risk Analysis}

In 2004, the CCB's capital adequacy ratio and core capital adequacy ratio were at a relatively low level, and then the trend was rising until 2015. The capital adequacy ratio and core capital adequacy ratio in 2005, had a significant increase, but in 2006, 2009 and 2013, they had a significant decline. The asset-liability ratio from 2004 to 2015, twisted and turned down, but it markedly increased in 2006 and 2009. Combined with the introduction of the $\mathrm{BOA}$, several major events of $\mathrm{CCB}$, we could find that the investment of the $\mathrm{BOA}$ in 2005 led to the rise of (core) capital adequacy ratio and a substantial decline in asset-liability ratio. In 2006 the change of indicators was due to the CCB's acquisition of the BOA (Asia). The BOA's reduction in 2009, 
and clearing all the shares in 2013, led to a decline in capital adequacy ratio of CCB and an increase in asset- liability ratio to a certain extent.

Overall, after the introduction of the BOA, the capital risk was fluctuating, but the trend was good, and the capital risk has declined. Even if the BOA completely left CCB in 2013, the trend of the indicators has not changed, that means $\mathrm{CCB}$ had been well protected against the divestment shock of strategic investors.

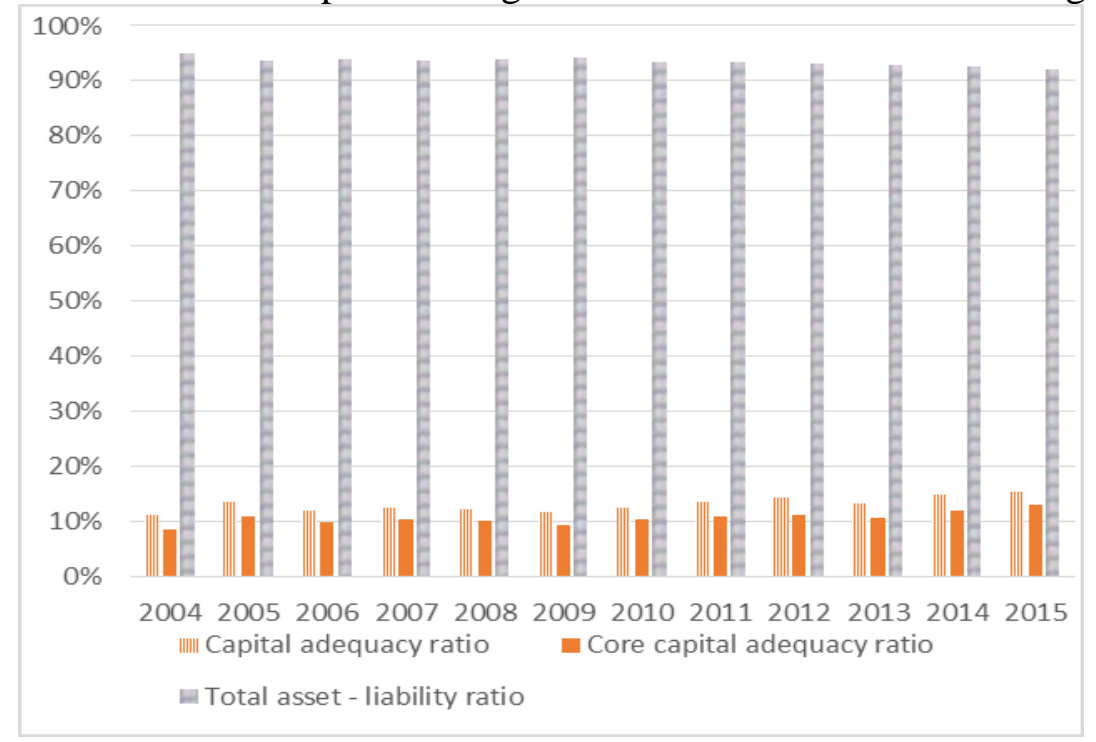

Fig.1 Changes of Capital Risk Indexes during 2004-2015

Source: Annual Reports of the CCB

\subsection{Asset Quality Risk Analysis}

The non-performing loan ratio of the CCB was declining from 2004 to 2013 , but it was not obvious in 2004 and 2005. However, the decline trend was obvious from the introduction of the BOA. The asset quality of BOA was in a good momentum of continuous improvement. The total non-performing loan ratio dropped to $1 \%$. But in 2014 and 2015, the non-performing loan rate began to rise, and it reached $1.58 \%$ in 2015 . The provision coverage ratio represents the ability of resisting risks for a bank to a certain extent. After the introduction of the BOA in 2005, the provision coverage ratio of CCB started to increase rapidly. But in 2013 the provision coverage declined slightly; what was worse, it went through a substantial decline in 2014 and 2015. As to loan concentration, the proportion of the top ten customers of the CCB dropped from $28.38 \%$ in 2005 to $14.46 \%$ in 2015, and the proportion only increased slightly in 2008 and 2015.

The continuous decline of the non-performing loan ratio and customer concentration ratio and the increase of provision coverage ratio all indicated that the CCB's risk prevention level were increasing from 2004 to 2012, and the BOA's shareholding had played a role. However, after the withdrawal in 2013, the CCB's non-performing loan ratio began to rise and provision coverage dropped sharply, probably because the CCB was heavily dependent on the BOA's technical support, and there was no actual control of the BOA's risk management technology.

\subsection{Liquidity Risk Analysis}

The proportion of asset liquidity of the CCB had been fluctuating, falling to $39.05 \%$ in 2006 and rising to $56.73 \%$ in 2012. After 2013, the liquidity of assets declined sharply and went to $44.17 \%$ in 2015 , below the industry average of $46.18 \%$, which meant there was a big risk. The proportion of deposits and loans of the CCB in 2004-2015 increased slightly after the first drop. The deposit-loan ratio was almost between $60 \%$ and 70\%. In 2015, the People's Bank of China announced the cancellation of deposit and loan ratio of $75 \%$, but the CCB's loan-to-deposit ratio declined in 2015, indicating that the growth of its loan size did not keep up with the rhythm of expansion of deposits and the CCB's operating cost was high. 


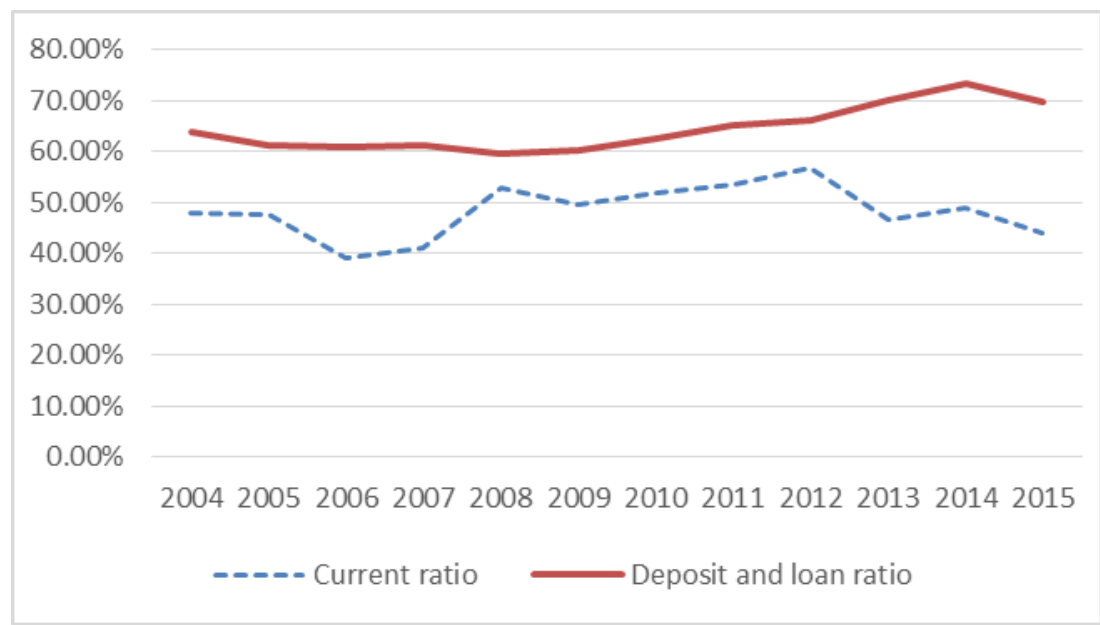

Fig. 2 Changes of Liquidity Risk Indexes during 2004-2015

Source: Annual Reports of the CCB

In general, the high proportion of deposits and loans of the $\mathrm{CCB}$, and a decrease in the proportion of liquidity meant the risk of liquidity was increasing. The adjustment of the People's Bank of China monetary policy also improved the competition between banks. The introduction of BOA did not bring significant decrease in the liquidity risk of CCB.

\subsection{Profitability Risk Analysis}

The asset profit ratio had been in the $1.29 \%$ average with little fluctuation from 2004 to 2015 , in addition to less than $1 \%$ in 2006; the CCB's rate of return on capital in 2004 reached a maximum of $22.99 \%$, but in 2005 and 2006 capital profit ratio declined, probably due to the introduction of the BOA in 2005 and acquisition of the BOA (Asia). The capital profit ratio began to rise steadily from 2007, but declined in 2011, and the placement of additional shares of the CCB might be the reason; the EPS rose from 0.26 yuan in 2004 to 0.91 yuan in 2015 , with an increase of 2.5 times, which showed an outstanding performance.

From the above three indicators, we could know from 2004 to 2006, the profitability of CCB had declined, which might be influenced by the introduction of the BOA. From 2007 to 2015, CCB achieved relatively rapid growth. Despite the decline in capital profit rate due to the expansion of capital scale, the profitability of CCB improved overall and the profitability risk decreased.

Table 2

Changes in profitability risk indicators

\begin{tabular}{lllllllllllll}
\hline Year & 2004 & 2005 & 2006 & 2007 & 2008 & 2009 & 2010 & 2011 & 2012 & 2013 & 2014 & 2015 \\
\hline $\begin{array}{l}\text { Asset Profit } \\
\text { Ratio (\%) }\end{array}$ & 1.31 & 1.11 & 0.92 & 1.15 & 1.31 & 1.24 & 1.32 & 1.47 & 1.47 & 1.47 & 1.42 & 1.30 \\
\hline $\begin{array}{l}\text { Rate of return } \\
\text { on capital (\%) }\end{array}$ & 9 & 5 & 0 & 0 & 8 & 7 & 1 & 1 & 8 & 3 & 4 & 7 \\
\hline EPS (RMB) & 0.26 & 0.24 & 0.21 & 0.30 & 0.40 & 0.45 & 0.56 & 0.68 & 0.77 & 0.86 & 0.91 & 0.91 \\
\hline
\end{tabular}

Source: Annual Reports of the CCB

\subsection{A Summary of the Indexes Analysis}

According to the above analysis, before the withdrawal in 2013, the BOA helped reduce the risk of the CCB. But the BOA's reducing behaviour of the stock in 2009 had brought impact to the CCB. In 2013 the BOA was completely out of the $\mathrm{CCB}$, then the CCB's asset quality began to decline and asset liquidity weakened which meant the risk was increasing. It can be seen that the BOA surely helped in some aspects, but its investment period was not long enough to go to the core content of the CCB, and the BOA's withdrawal had brought undesirable influence which caused the effect of risk improvement was not good as expected. 


\section{Conclusions}

The introduction of foreign strategic investors can enhance the strength of the commercial banks in some aspects, but the introduction is not always effective. In order to improve the effect of foreign investment, the commercial banks should do the followings. (1) Choosing the investor carefully. When selecting a strategic investor, a commercial bank should be alert to its short-term speculation and choose a partner with strong comprehensive strength and long-term willingness to cooperate. (2) Establishing a risk management mechanism. Considering that overseas strategic investors may sell shares in cooperation, commercial banks should establish a risk management mechanism to deal with the strategic investors' reducing behavior in order to maintain the market's stability. (3) Establishing the exit mechanism. In order to reduce the negative impact of a large-scale divestment, the two sides should make it clear that the larger-scale divestment must be carried out in gradual stages. (4) Improving their abilities. The effect of the introduction is uncertain now, which means the introduction is only an auxiliary way, and it is wise to enhance their ability after the introduction of foreign capital. So the commercial banks will not suffer from risk shock even if the foreign investment is gone.

\section{References}

[1] Sun Yijun, Lan Xiangming. The Performance Evaluation of China's Banking Industry Introducing Foreign Strategic Investors. Journal of Zhongnan University of Economics and Law.47-52+142 (2008).

[2] Zhang Ao. A Review of Introducing Strategic Investors in Chinese Commercial Banks. Wuhan Finance Monthly. 14-15 (2008).

[3] Lu Jiayuan, Kong Aiguo. The Impact of Foreign Strategic Investors on Chinese Commercial Banks. Shanghai Finance.86-89 (2009).

[4] Zhang Zongyi and Song Zengji. Research on the Effect of Foreign Strategic Investors' Ownership of Chinese Listed Banks. Nankai Business Review. 106-114 (2010).

[5] Zhu Yingying, Li Ping, Zeng Yong, and He Jia. Attracting Foreign Capital, Introducing Intelligence and Quoting: An Empirical Study on Chinese - Funded Banks' Introducing Overseas Strategic Investors. China Soft Science.70-80+105 (2010).

[6] Alvaro G Taboada. The impact of changes in bank ownership structure on the allocation of capital: International evidence. Journal of Banking \& Finance. Volume 35. 2528-2543 (2011).

[7] Zhu Yingying. An Empirical Study on the Effect of Chinese Banks Introducing Foreign Strategic Investors. University of Electronic Science and Technology of China. (2011)

[8] Li Jiali. A Study on the Influence of Introducing Foreign Strategic Investors on the Financial Risks of China's Commercial Banks - Taking Huaxia Bank as an Example. Southwestern University of Finance and Economics. (2014)

[9] Wei Tao. Chinese and Foreign Equity Cooperation, Intangible Resources Optimization and International Competitiveness. Journal of Henan Normal University . 77-81 (2016).

[10] Xing Huabing and Pang Zhi. Reflections on the Introduction of Non-State-Owned Shareholders in State-owned Commercial Banks. Finance of Wuhan.48-52 (2016). 